\title{
A Novel Bioanalytical Method for the Determination of Opioids in Blood and Pericardial Fluid
}

\author{
Elisa Ferreira ${ }^{1,2}$, Francisco Corte Real ${ }^{1,3}$, Teresa Pinho e Melo ${ }^{2}$ and \\ Cláudia Margalho ${ }^{1, *}$
}

${ }^{1}$ Instituto Nacional de Medicina Legal e Ciências Forenses, I.P. (INMLCF, I.P.), Laboratório de Toxicologia Forense da Delegação do Centro, Azinhaga de Santa Comba - Polo das Ciências da Saúde, 3000-548 Coimbra, Portugal; ${ }^{2}$ Departamento de Química da Faculdade de Ciências e Tecnologia da Universidade de Coimbra, R. Larga 2, 3004535 Coimbra, Portugal and ${ }^{3}$ Faculdade de Medicina da Universidade de Coimbra, Azinhaga de Santa Comba - Polo das Ciências da Saúde, 3000-548 Coimbra, Portugal

*Author to whom correspondence should be addressed. Email: claudia.i.margalho@inmlcf.mj.pt

\begin{abstract}
Opioids are the drugs most commonly detected in overdose deaths and the second most consumed worldwide. An analytical methodology has been optimized and fully validated for the determination of codeine, morphine, 6-acetylmorphine, 6-acetylcodeine, oxycodone, oxymorphone and fentanyl in whole blood and pericardial fluid. The internal standards used were codeine- $d_{3}$, morphine$d_{3}, 6$-acetylmorphine- $d_{3}$ and fentanyl- $d_{5}$. Before solid-phase extraction, volumes of $250 \mu \mathrm{L}$ of blood and pericardial fluid were subjected to a protein precipitation (with $750 \mu \mathrm{L}$ of ice-cold acetonitrile) and a microwave-induced oximation was performed using a solution of $1 \%$ aqueous hydroxylamine hydrochloride in phosphate-buffered saline $(1: 2, \mathrm{v} / \mathrm{v})$. Finally, the dried extracts were further derivatized with a solution of $n$-methyl- $n$-(trimethylsilyl) trifluoroacetamide $+5 \%$ trimethylchlorosilane under microwave irradiation. The chromatographic analysis was carried out using gas chromatography-mass spectrometry operating in electron impact and selected ion monitoring mode. For all analytes, the method was linear between 5 and $1,000 \mathrm{ng} / \mathrm{mL}$ with determination coefficients $\left(r^{2}\right)>0.99$. Depending on the analyte and matrix, the limit of detection varies between 3 and $4 \mathrm{ng} / \mathrm{mL}$. Intra- and intermediate precision $(<20 \%)$ and bias $( \pm 20 \%)$ were acceptable for all analytes in both matrices. The stability of the substances in the studied matrices was guaranteed, at least, $24 \mathrm{~h}$ in the autosampler, $4 \mathrm{~h}$ at room temperature and 30 days after three freeze/thaw cycles. This methodology was applied to real samples from the Laboratory of Chemistry and Forensic Toxicology, Centre Branch, of the National Institute of Legal Medicine and Forensic Sciences, Portugal.
\end{abstract}

\section{Introduction}

Opioids are classified as natural (e.g., morphine, codeine), semisynthetic (e.g., oxycodone, heroin, oxymorphone) and synthetic (e.g., fentanyl) compounds (1-4). They can also be classified according to their affinity for different opioid receptors $\mu$ (mu), $\kappa$ (kappa), $\delta$ (delta) and $\sigma$ (sigma), as pure agonist (morphine, fentanyl and oxycodone), partial agonist/antagonist and as agonist/antagonist (3,
5-8). These receptors have inhibitory effect and are distributed in the brain, spinal cord and peripheral nervous system $(7,9)$. Several effects are associated with its consumption, such as analgesia, respiratory depression, nausea and vomiting, euphoria, sedation, miosis, dry mouth, antitussive effect, hypotension and bradycardia, constipation, contraction of the sphincter of Oddi and vesical, cognitive changes (hallucinations, delusions) and tolerance $(5-7,10)$. In spite of 
this, opioids are prescribed and used mainly for pain management, although they are sometimes overused by patients and also used as recreational drugs (4).

Overdoses deaths are caused mainly to induced coma, respiratory depression, which will trigger apnea and consequently death $(5,7$, 11). The effects of these substances begin to appear between $<25 \mathrm{~min}$ and $1 \mathrm{~h}$ and they have distribution volumes of $1-25 \mathrm{~L} / \mathrm{kg}$. Elimination ratio varies from substance to substance $(11,12)$.

Opioids are the second most widely used drug in the world and the most detected in deaths related to overdoses. According to annual reports, opioids were detected in 76,84 and $42 \%$ of fatal overdoses in the world, Europe and Portugal, respectively (13-15). Seizure of opioids other than heroin has increased in 2016 and 2017, including methadone, tramadol, fentanyl derivatives, morphine, opium, codeine and oxycodone. Also, treatment entrants indicated misused of methadone, buprenorphine, fentanyl, codeine, morphine, tramadol and oxycodone $(14,16)$. Due the synthetic opioids crisis of fentanyl, its analogs and tramadol, affecting mainly North America and parts of Africa, Asia and the Middle East, respectively, the United Nations Office on Drugs and Crime (UNODC) launched in June 2018 an integrated strategy to support countries facing this problem (17). In this context, it is important to develop analytical methodologies that identify and quantify these substances in several biological matrices. To perform the analysis, blood (BL) is one of the most important matrices, but collection is not always feasible (e.g., severe exsanguination, advanced putrefaction). Therefore, it is important to have an alternative or even a complementary biological matrix, such as pericardial fluid $(\mathrm{PF})$, which can provide relevant information. In forensic toxicology, the use of PF has several advantages such as the volume available to be collected (between 5 and $35 \mathrm{~mL}$ ), it is easily obtained from the pericardial cavity, is well protected from contamination by pathogens and relatively stable during the postmortem period (18-22). However, if a huge quantity of a drug is present in the stomach, PF can be contaminated by postmortem diffusion (21). Despite the scarce existing studies, they suggest a good or moderate correlation between $\mathrm{PF}$ and peripheral $\mathrm{BL}$, and recommend its inclusion to the routine autopsy specimens $(19,20,23)$.

Concerning to the studied opioids in PF, the published studies are scarce, comprising only codeine $(18,23)$, morphine $(18,20,24)$ and 6-acetylmorphine (6-MAM) (24).

In this study, solid-phase extraction (SPE) was implemented due to its several advantages, namely, high reproducibility, efficiency, quickness, use of a smaller sample volume and production of less solvent waste. Liquid-liquid extraction, in turn, requires larger amounts of sample and solvents (some flammable and/or toxic) and can lead to the formation of emulsions with mutual solubility of the analytes in both phases $(5,25,26)$.

In opioid determination, the sample pretreatment using deproteinization with acetonitrile prior to the SPE and chromatographic analysis by gas chromatography coupled with mass spectrometry (GC-MS) offers the great advantage of eliminating the matrix effect [a problem associated with analysis by liquid chromatography coupled to mass spectrometry (LC-MS)] and simultaneously allows the quantification of very low concentrations of substances in small volumes of biological samples (27). However, it requires a derivatization step to improve opioids detectability and stability $(28,29)$. Silylation or fluoroacetylation are the preferred methods for opioids derivatization. Oxycodone and oxymorphone, being keto-opioids, may originate multiple derivatives (via tautomerization) as their carbonyl group may be in an enol or keto form, which can compromise the achievement of an accurate quantification of these substances $(28,30-34)$. One way to avoid the formation of these derivatives and improve the chromatographic resolution of the compounds is to perform the reaction with hydroxylamine to form the corresponding oximes, prior to other derivatizations (namely the addition of trimethylsilyl or propionyl groups). With the inclusion of this crucial step (oximation) in the preparation of the samples, the formation of oximes derivatives and multiple derivatization of these compounds is avoided. This multiple derivatization is due to the tautomerization that will permit the formation of products from the enol isomer and from the unreacted keto isomer. It must be highlighted that the addition of hydroxylamine does not affect the other opioids [codeine, morphine, 6-MAM, 6-acetylcodeine (6-ACCOD) and fentanyl] since their structures do not have a functional ketone group (30, 31, 33, 35-42). There are also studies that used methoxylamine (30, 34, 35, 43-47) as derivatization reagent.

The use of microwave-assisted derivatization for the determination of drugs of abuse by GC-MS has already been published (29, 48-53). However, we did not find any studies on the substance in the current study that used microwave-induced oxime derivatizations. Thus, we present a fast microwave-assisted derivatization procedure using hydroxylamine with a reaction time of just $30 \mathrm{~s}$, much shorter than found in other publications: $15 \min (34,35,37,39$, 40, 45), $20 \min (47), 30 \min (36,44,46), 60 \min (30,31,33,38,42$, 43) or $120 \mathrm{~min}$ (41). A final fast microwave-assisted derivatization using $n$-methyl- $n$-(trimethylsilyl) trifluoroacetamide (MSTFA) $+5 \%$ trimethylchlorosilane (TMCS), requiring only $100 \mathrm{~s}$ instead of the $15-20 \mathrm{~min}(31,33,36,39-42,45,47), 30 \mathrm{~min}(30,37,44)$ or $60 \mathrm{~min}$ (38) spent in other published studies, was also described.

The aim of this work was the development, optimization and validation of an analytical methodology for confirmation and quantification of codeine, morphine, 6-MAM, 6-ACCOD, oxycodone, oxymorphone and fentanyl using only $250 \mu \mathrm{L}$ of $\mathrm{BL}$ and $\mathrm{PF}$ with application of two steps of fast microwave-assisted derivatization, which reduced the total analysis time remarkably. To the best of our knowledge, this is the first developed methodology for the simultaneous determination of these seven opioids in postmortem matrices, under the studied conditions.

\section{Experimental}

\section{Chemicals and reagents}

The analytical standards of codeine and morphine were purchased from Lipomed AG (Arlesheim, Switzerland). The substances, 6-MAM, 6-ACCOD, oxycodone, oxymorphone, fentanyl and the internal standards (IS), codeine- $\mathrm{d}_{3}, 6-\mathrm{MAM}_{3} \mathrm{~d}_{3}$, fentanyl- $\mathrm{d}_{5}$ and morphine- $\mathrm{d}_{3}$ were supplied from Cerilliant (Round Rock, TX, USA). Acetonitrile and deionized water were purchased from Riedel-de Haën (Seelze, Germany). Carbonate buffer $(0.15 \mathrm{M}$ at $\mathrm{pH}=9.5)$, dichloromethane, 2-propanol, ammonium, $n$-hexane, TMCS and hydroxylamine hydrochloride $99 \%$ were acquired from Merck Co. (Darmstadt, Germany), MSTFA from Macherey-Nagel GmbH \& Co. (Düren, Germany), phosphate-buffered saline (PBS, $0.1 \mathrm{M}$ at $\mathrm{pH}=7$ ) and purified water from VWR (Radnor, PA, USA). Oasis ${ }^{\circledR}$ MCX extraction cartridges $(3 \mathrm{~mL}, 60 \mathrm{mg}$ ) were purchased from Waters Corp. (Milford, MA, USA).

\section{Biological samples}

Blank BL samples were acquired from a local BL bank and used for calibration purposes and validation experiments. The blank 
PF was collected during autopsies performed at the Medico-Legal Offices of the National Institute of Legal Medicine and Forensic Sciences, Centre Branch, Portugal and were also used for calibration purposes and validation experiments. All samples were stored at $-15^{\circ} \mathrm{C}$ and screened for drugs of abuse before being used.

\section{Apparatus}

A Turbo Vap ${ }^{\circledR}$ LV (Caliper Life Science) with nitrogen gas was used for the solvents evaporation. The chromatographic analyses were achieved using an Agilent Technologies 7890B GC system (Hewlett-Packard, Waldbronn, Germany), coupled with a 5977A, mass-selective detector (Hewlett-Packard).

\section{Methods}

\section{Preparation of standard solutions, calibrators and controls}

Stock solutions of each substance $(50 \mu \mathrm{L} / \mathrm{mL})$ were prepared in methanol with exception of 6-ACCOD, which was prepared in acetonitrile. Working solutions of quality control (QC) and calibrators at $5 \mu \mathrm{g} / \mathrm{mL}$ were prepared in the corresponding solvents (acetonitrile for ACCOD and methanol for the remaining compounds) and then by proper dilution were prepared at 0.5 and $0.05 \mu \mathrm{g} / \mathrm{mL}$. An internal working standard solution (mixture of codeine- $\mathrm{d}_{3}$, morphine- $\mathrm{d}_{3}, 6$ MAM- $\mathrm{d}_{3}$ and fentanyl- $\mathrm{d}_{5}$ ) at $2 \mu \mathrm{g} / \mathrm{mL}$ was prepared in methanol. Working solutions and stock solutions were stored at a temperature of 5 and $-20^{\circ} \mathrm{C}$, respectively, and protected from light.

\section{Sample preparation and extraction}

After the addition of $25 \mu \mathrm{L}$ of the deuterated IS solution to volumes of $250 \mu \mathrm{L}$ of $\mathrm{PF}$ and $\mathrm{BL}$, a protein precipitation of the samples was performed by the addition of $750 \mu \mathrm{L}$ of ice-cold acetonitrile and centrifuged at 3,000 rpm for $10 \mathrm{~min}$. The supernatant was decanted into clean glass tubes, and $375 \mu \mathrm{L}$ of the $1 \%$ aqueous hydroxylamine hydrochloride in PBS (1:2, v/v) solution (prepared freshly) was added, agitated and derivatized in a microwave reactor of $900 \mathrm{~W}$ at $50 \%$ power during $30 \mathrm{~s}$. After cooling down to room temperature, the samples were added to the extraction cartridges, beforehand conditioned with $1 \mathrm{~mL}$ methanol and $1 \mathrm{~mL}$ of deionized water. Then, the cartridges were washed sequentially with $1 \mathrm{~mL}$ carbonate buffer $(0.15 \mathrm{M}), 1 \mathrm{~mL}$ of deionized water and $1.5 \mathrm{~mL}$ of $n$-hexane. After the columns were dried under full vacuum, the analytes were eluted with $1 \mathrm{~mL}$ of a mixture of dichloromethane:2-propanol:ammonium $(78: 20: 2, \mathrm{v} / \mathrm{v} / \mathrm{v})$. The extracts were evaporated at $40^{\circ} \mathrm{C}$ under a gentle nitrogen stream (until dryness). Lastly, derivatization was performed by addition of $60 \mu \mathrm{L}$ of MSTFA $+5 \%$ TMCS over $100 \mathrm{~s}$ at $100 \%$ power in a microwave reactor of $900 \mathrm{~W}$. After cooling down to room temperature, the solutions were transferred to the GC autosampler vials and $2 \mu \mathrm{L}$ injected into the GC-MS system.

\section{GC-MS conditions}

A capillary column HP-5 MS with 5\% phenylmethylsiloxane (30 $\mathrm{m} \times 0.25 \mathrm{~mm}$ I.D., 0.25 -mm film thickness) supplied by J\&W Scientific (Folsom, CA, USA) was used.

The oven temperature program was as follows: $50^{\circ} \mathrm{C}$ held for $1 \mathrm{~min}$, increased to $300^{\circ} \mathrm{C}$ at $20^{\circ} \mathrm{C} / \mathrm{min}$ and held for $2 \mathrm{~min}$. Highly purified helium was the carrier gas at a constant flow rate of 1 $\mathrm{mL} / \mathrm{min}$, and it was used in splitless injection mode $(2 \mu \mathrm{L})$. The
Table I. RTs and Monitored lons of Each Substance

\begin{tabular}{|c|c|c|}
\hline Analytes & Ions $(\mathrm{m} / \mathrm{z})$ & $\mathrm{RT}(\min )$ \\
\hline Codeine- $\mathrm{d}_{3}$ & $374^{a}$ & 13.58 \\
\hline Codeine & $371^{\mathrm{a}}, 178,196$ & 13.59 \\
\hline Morphine- $\mathrm{d}_{3}$ & $432^{\mathrm{a}}$ & 13.79 \\
\hline Morphine & $429^{a}, 236,414$ & 13.80 \\
\hline 6-ACCOD & $341^{\mathrm{a}}, 282,229$ & 13.92 \\
\hline 6-Aceylmorphine- $\mathrm{d}_{3}$ & $402^{\mathrm{a}}$ & 14.10 \\
\hline 6-MAM & $399^{\mathrm{a}}, 287,340$ & 14.11 \\
\hline Oxycodone & $474^{\mathrm{a}}, 459,475$ & 14.38 \\
\hline Oxymorphone & $532^{\mathrm{a}}, 517,533$ & 14.40 \\
\hline Fentanyl-d ${ }_{5}$ & $250^{\mathrm{a}}$ & 14.87 \\
\hline Fentanyl & $245^{\mathrm{a}}, 189,146$ & 14.89 \\
\hline
\end{tabular}

${ }^{\mathrm{a}} \mathrm{Quantification} \mathrm{ions.}$

mass spectrometer worked with an emission current of $300 \mu \mathrm{A}$ in the electron ionization mode with an electron energy of $70 \mathrm{eV}$. The temperatures of the injection port and detector were set at 250 and $280^{\circ} \mathrm{C}$, respectively. Initially, the retention times (RTs) and characteristics ions of the substances were identified with a full scan mode (scan range $50-550 \mathrm{~m} / \mathrm{z}$ ), and then the analyses were performed with a selected ion monitoring mode. The IS used to quantitate each substance were the following: codeine- $\mathrm{d}_{3}$ for codeine and 6 ACCOD, morphine- $\mathrm{d}_{3}$ for morphine, oxymorphone and oxycodone, 6-MAM- $\mathrm{d}_{3}$ for 6-MAM and fentanyl- $\mathrm{d}_{5}$ for fentanyl, since these were available and the most similar to the substances. The ions monitored for each substance are presented in Table I in ascending order of their RTs.

\section{Method validation}

The described procedure was validated by evaluating interferences, linearity, limits of detection (LOD) and limits of quantification (LOQ), carryover, precision (intraday and intermediate), bias, stability (autosampler, benchtop and freeze/thaw cycles), dilution integrity and recovery based on the recommendations of the Scientific Working Group for Forensic Toxicology (SWGTOX) (54).

\section{Acceptance criteria for compounds identification}

The criteria for identification of compounds were established according to the recommendations of the World Anti-Doping Agency (55). For chromatography, the relative RT of the substance must fall within a $1 \%$ window, or $\pm 0.1 \mathrm{~min}$ in absolute terms, from that of the same substance in a QC sample prepared and analyzed contemporaneously. Mass spectrometric identification must include at least three diagnostic ions, and their relative intensities should not differ by more than a tolerated amount from those generated by the same substance in a QC sample prepared and analyzed contemporaneously (if the relative intensity of the ion is within a $25-50 \%$ interval of the base peak in the control sample, a maximum relative tolerance of $20 \%$ will be allowed for the same ion in the sample; if this intensity is $<25 \%$ or $>50 \%$ in the control sample, then absolute tolerances of 5 and $10 \%$, respectively, will be allowed for the ion in the sample). A signal-to-noise ratio greater than three to one $(3: 1)$ of all diagnostic ions is also required (55). 


\section{Interference study}

Interferences were studied by analyzing one group of 10 different blank samples of both matrices (BL and PF) spiked with the substances most commonly found in routine analyses of the SQTF$\mathrm{C}$ (medicines, drugs of abuse and pesticides) at 5 and $100 \mathrm{ng} / \mathrm{mL}$ and one group of 10 different blank samples of both matrices only fortified with the IS. The interferences used were amisulpride; amitriptyline; amlodipine; aripiprazole; atenolol; bisoprolol; buprenorphine; bupropion; buspirone; carbamazepine; carvedilol; ciamemazine; citalopram; clomipramine; clonazepam; chlorpromazine; clozapine; diltiazem; dosulepine; doxylamine; duloxatine; esmolol; phenytoin; phenobarbital; felbamate; fluphenazine; fluoxetine; fluvoxamine; gabapentin; haloperidol; hydrochlorothiazide; imipramine; indapamide; ketamine; lamotrigine; lercanidipine; levetiracetam; lidocaine; maprotiline; melperone; methadone; metoprolol; mianserin; mirtazapine; nifedipine; nimesulide; nortriptyline; olanzapine; oxcarbazepine; paliperidone; paracetamol; paroxetine; pentobarbital; pethidine (meperidine); primidone; promethazine; propafenone; propranolol; quetiapine; risperidone; sertraline; sildenafil; tadalafil; telmisartan; tapentadol; tiapride; tiopental; tramadol; trazodone; trimipramine; vardenafil; warfarin; venlafaxine; zisprasidone; zolpidem; THC; $\mathrm{THCOH}$; $\mathrm{THCCOOH}$; cocaine; benzoylecgonine; ecgoninamethylester; d,l-amphetamine; d,l-methamphetamine; d,1-MDA; d,l-MDMA; d,1-MDEA; d,1MBDB; mephedrone; methedrone; d,l-methcathinone; d-cathine; 1s,2r(+)-ephedrine; d,l-DCB; d,l-PMA; 2C-B; 2C-H; 2C-I; 2C-T-2; 2C-T-4; 2C-T-7; MDPV; $\alpha$-pVP; pentylone, r(-)-Bromo DragonFLy; d,l-NNDMA; methylone; d,l-4-MTA; 2C-P; ethylone; buphedrone; flephedrone; $\mathrm{r}(+)$-cathinone; azinfos ethyl; azinfos methyl; chlorfenvinphos; chlorpyrifos; chlorpyrifos methyl; demeton-s-methyl sulfone; diazinon; dimethoate; etoprophos; fenamiphos; fenthion; phosalone; foxime; malathion; methamidophos; methidathion, mevinphos; ometoate; paraoxon; parathion ethyl; parathion methyl; quinalfos; sulfotep and terbufos. This parameter was studied to investigate the presence of matrix interferences at the RT of monitored ions for each compound and respective IS, and also the method's ability to identify the substances of interest in the presence of other compounds routinely analyzed in the laboratory.

\section{Linearity, LOD and LOQ and carryover}

Linearity was determined by plotting the peak area ratio between the analyte of interest and its IS against theoretical concentrations. The acceptance criteria were $r^{2} \geq 0.99$ and the calibrators quantified within $\pm 20 \%$. Simultaneously, four different QC samples at 5, 25, 200 and $900 \mathrm{ng} / \mathrm{mL}$ and blank samples of BL and PF with IS added were also analyzed.

The LODs were determined as the lowest concentrations with a signal/noise ratio $\geq 3$. The LOQs were defined as the minimum concentration of each substance that could be quantified with adequate precision (coefficient of variation, CV $<20 \%$ ) and bias $( \pm 20 \%)$. Carryover was analyzed by injecting blank samples after the highest concentration of the calibration curve and verifying if it was present ionic signals of the substances of interest at their RTs that will affect the capability to confirm them.

\section{Precision and bias}

Precision was determined by calculating the CV (\%) and acceptable values should be $<20 \%$. Bias was calculated on each group of QC samples: [ $($ mean of measured concentrations - theoretical concentration)/theoretical concentration $\times 100$ ] and the limit of the acceptable variability was $\pm 20 \%$. Intraday precision was determined by analyzing four QC samples levels in both matrices at the same day. The intermediate precision and bias were determined by the analysis of QC samples at three concentration levels (low, medium and high) in both matrices on five different days. Precision was acceptable when $\mathrm{CV}<20 \%$ and bias was acceptable when the value measured was $\pm 20 \%$ of the spiked concentration, for all QC samples.

\section{Stability}

The stability on the autosampler was examined at three QC levels (low, medium and high) by reinjecting the extracts after $24 \mathrm{~h}, 48 \mathrm{~h}$, and 7 days, under the conditions of the GC-MS laboratory. This parameter was evaluated by comparing the mean concentration obtained in each of the days $(n=3)$, with the mean concentration of the freshly extracts obtained on the first day $(n=3)$. Benchtop stability and the three freeze/thaw cycles (after 1, 2, 3 and 4 weeks) were performed with two different QC levels (low and medium). Benchtop evaluation was done analyzing the QC samples leaved at room temperature for $4 \mathrm{~h}$ and compared with freshly spiked QC samples at the same concentrations. The evaluation of freeze/thaw cycles was done with the two levels QC samples frozen at $-15^{\circ} \mathrm{C}$ and thawed after the referred periods. Stability was considered acceptable if percentage of loss was within $\pm 20 \%$ of the freshly prepared QC samples.

\section{Dilution integrity}

This parameter was evaluated by diluting fortified QC samples (BL and $\mathrm{PF}$ ) at $1150 \mathrm{ng} / \mathrm{mL}$ samples to achieve 1:2 dilution; prior protein precipitation IS was added to the samples and the methodology previously described was applied. Dilution integrity is accepted if substances quantify within $\pm 20 \%$ of the concentration $1,150 \mathrm{ng} / \mathrm{mL}$ after the mentioned dilution.

\section{Recovery}

The extraction efficiency was estimated by analysis of two sets of three different concentration levels (low, medium and high) in which the IS was added after the extraction. This parameter was determined comparing average blank samples fortified before extraction (set 1, $n=6$ ), with average blank samples fortified after the extraction (set $2, n=6$ ): set $1 /$ set $2 \times 100 \%$.

\section{Results and Discussion}

The procedure described above was full validated in BL and PF obtaining appropriate results using only $250 \mu \mathrm{L}$ of samples. All compounds were well separated chromatographically in $15 \mathrm{~min}$. In both blank matrices (BL and PF), no significant interferences (endogenous and exogenous) were observed at $\mathrm{m} / \mathrm{z}$ of the monitored ions and at their RTs. All the studied substances were successfully identified in the fortified matrices, suggesting that the added compounds do not interfere with the analysis of the analytes of interest.

Linearity was verified in BL and PF samples from 5 to $1,000 \mathrm{ng} / \mathrm{mL}$, using eight different points for each compound and $1 / \mathrm{x}$ weighted factor. The $1 / \mathrm{x}$ weighting linear regression model was suitable to all calibration curves obtaining $r^{2} \geq 0.99$ and calibrators quantitated within $\pm 20 \%$. The LODs achieved in BL were $4 \mathrm{ng} / \mathrm{mL}$ for all analytes except for oxymorphone and fentanyl $(3 \mathrm{ng} / \mathrm{mL})$. 
Table II. Linearity Results for All Analytes Studied in BL and PF

\begin{tabular}{|c|c|c|c|c|c|c|}
\hline \multirow[t]{2}{*}{ Analytes } & \multirow[t]{2}{*}{ Matrix } & \multirow{2}{*}{$\begin{array}{l}\text { Linear range } \\
(\mathrm{ng} / \mathrm{mL})\end{array}$} & \multicolumn{3}{|c|}{ Linearity } & \multirow[t]{2}{*}{$\mathrm{LOD}^{\mathrm{b}}$} \\
\hline & & & Slope $\left({ }^{\mathrm{a}}\right)$ & Intercept $\left({ }^{\mathrm{a}}\right)$ & $r^{2}\left({ }^{\mathrm{a}}\right)$ & \\
\hline \multirow[t]{2}{*}{ Codeine } & $\mathrm{BL}$ & $5-1,000$ & $5.8 \mathrm{E}-03 \pm 3.9 \mathrm{E}-04$ & $1.5 \mathrm{E}-02 \pm 1.3 \mathrm{E}-03$ & $0.999 \pm 1.2 \mathrm{E}-03$ & 4 \\
\hline & $\mathrm{PF}$ & & $8.9 \mathrm{E}-03 \pm 2.6 \mathrm{E}-03$ & $1.2 \mathrm{E}-02 \pm 5.4 \mathrm{E}-03$ & $0.999 \pm 1.2 \mathrm{E}-04$ & 3 \\
\hline \multirow[t]{2}{*}{ Morphine } & $\mathrm{BL}$ & $5-1,000$ & $5.39 \mathrm{E}-03 \pm 1.56 \mathrm{E}-04$ & $2.73 \mathrm{E}-02 \pm 1.47 \mathrm{E}-02$ & $0.998 \pm 1.41 \mathrm{E}-03$ & 4 \\
\hline & $\mathrm{PF}$ & & $7.49 \mathrm{E}-03 \pm 1.91 \mathrm{E}-03$ & $6.37 \mathrm{E}-02 \pm 1.89 \mathrm{E}-02$ & $0.997 \pm 2.33 \mathrm{E}-03$ & 3 \\
\hline \multirow[t]{2}{*}{ 6-MAM } & $\mathrm{BL}$ & $5-1,000$ & $5.8 \mathrm{E}-03 \pm 5.5 \mathrm{E}-04$ & $1.3 \mathrm{E}-02 \pm 5.0 \mathrm{E}-04$ & $0.998 \pm 1.2 \mathrm{E}-03$ & 4 \\
\hline & $\mathrm{PF}$ & & $9.3 \mathrm{E}-03 \pm 3.0 \mathrm{E}-03$ & $1.5 \mathrm{E}-02 \pm 7.3 \mathrm{E}-03$ & $0.999 \pm 9.1 \mathrm{E}-05$ & 4 \\
\hline \multirow[t]{2}{*}{ 6-ACCOD } & $\mathrm{BL}$ & $5-1,000$ & $7.3 \mathrm{E}-03 \pm 6.9 \mathrm{E}-04$ & $2.3 \mathrm{E}-02 \pm 2.2 \mathrm{E}-02$ & $0.999 \pm 1.1 \mathrm{E}-03$ & 4 \\
\hline & $\mathrm{PF}$ & & $1.3 \mathrm{E}-02 \pm 4.5 \mathrm{E}-03$ & $3.1 \mathrm{E}-01 \pm 5.3 \mathrm{E}-01$ & $0.999 \pm 7.5 \mathrm{E}-05$ & 4 \\
\hline \multirow[t]{2}{*}{ Oxycodone } & $\mathrm{BL}$ & $5-1,000$ & $4.9 \mathrm{E}-03 \pm 1.4 \mathrm{E}-03$ & $-4.4 \mathrm{E}-03 \pm 5.3 \mathrm{E}-03$ & $0.998 \pm 2.4 \mathrm{E}-03$ & 4 \\
\hline & $\mathrm{PF}$ & & $5.1 \mathrm{E}-03 \pm 9.1 \mathrm{E}-04$ & $-7.2 \mathrm{E}-03 \pm 4.8 \mathrm{E}-03$ & $0.995 \pm 1.4 \mathrm{E}-03$ & 3 \\
\hline \multirow[t]{2}{*}{ Oxymorphone } & $\mathrm{BL}$ & $5-1,000$ & $4.5 \mathrm{E}-03 \pm 1.2 \mathrm{E}-03$ & $-1.7 \mathrm{E}-03 \pm 6.8 \mathrm{E}-03$ & $0.998 \pm 2.1 \mathrm{E}-03$ & 3 \\
\hline & $\mathrm{PF}$ & & $5.5 \mathrm{E}-03 \pm 1.1 \mathrm{E}-03$ & $-3.1 \mathrm{E}-03 \pm 8.9 \mathrm{E}-03$ & $0.995 \pm 2.8 \mathrm{E}-03$ & 3 \\
\hline \multirow[t]{2}{*}{ Fentanyl } & $\mathrm{BL}$ & $5-1,000$ & $5.6 \mathrm{E}-03 \pm 7.1 \mathrm{E}-04$ & $1.0 \mathrm{E}-02 \pm 5.7 \mathrm{E}-03$ & $0.999 \pm 8.3 \mathrm{E}-04$ & 3 \\
\hline & $\mathrm{PF}$ & & $9.0 \mathrm{E}-03 \pm 2.7 \mathrm{E}-03$ & $2.1 \mathrm{E}-02 \pm 3.4 \mathrm{E}-02$ & $0.999 \pm 5.4 \mathrm{E}-04$ & 3 \\
\hline
\end{tabular}

${ }^{\mathrm{a}}$ Mean values \pm standard deviation $(n=5) .{ }^{\mathrm{b}} n=6$.

For PF, all compounds reached LODs of $3 \mathrm{ng} / \mathrm{mL}$ with exception of 6-MAM and 6-ACCOD $(4 \mathrm{ng} / \mathrm{mL})$ as can be seen in Table II. The LOQs achieved in both matrices were $5 \mathrm{ng} / \mathrm{mL}$ for all substances (Figure $1 \mathrm{~A}$ and $\mathrm{B}$ ). Although in some previous studies lower values were achieved for LODs and LOQs much higher volumes of BL sample were used, between 1 and $3 \mathrm{~mL}$ (31, 33, 35, 37, 42, 47, 56-61). Related to PF, previous studies neither present values of LOD and LOQ using GC-MS, for codeine and morphine, nor the other compounds studied in this matrix, being impossible to make comparisons $(18,20,23)$. According to the few review articles published on the determination of opiates in biological matrices, we present some comparisons of results obtained for both LOD and LOQ taking in account the sample volume $(\mathrm{V})$ used and the chromatographic technology coupled with the mass spectrometry that was applied (GC-MS-MS and LC-MS-MS technologies) (27, 28). When LC-MS-MS was used, the LODs (LOQs) obtained in BL for morphine, codeine, 6-MAM, 6-ACCOD, oxycodone, oxymorphone and fentanyl are between 0.2 (0.7) and 7 (8) ng/mL (V = $1 \mathrm{~mL})(62,63) ; 0.09(0.44)(\mathrm{V}=100 \mu \mathrm{L})$ and $3(5) \mathrm{ng} / \mathrm{mL}(\mathrm{V}=1 \mathrm{~mL})(63-65) ; 0.05(5)(\mathrm{V}=100 \mu \mathrm{L})$ and 2 (3) ng/mL (V = $1 \mathrm{~mL})(63,66) ; 0.26(0.88)$ and $1(5) \mathrm{ng} / \mathrm{mL}$ $(\mathrm{V}=1 \mathrm{~mL})(62,64) ; 0.2(0.2)$ and $1(2) \mathrm{ng} / \mathrm{mL}(\mathrm{V}=1 \mathrm{~mL})(63$, 67); $0.29(0.98)(\mathrm{V}=1 \mathrm{~mL})$ and $0.3(1) \mathrm{ng} / \mathrm{mL}(\mathrm{V}=300-500 \mu \mathrm{L})$ $(68,69) ; 0.08(0.1) \mathrm{ng} / \mathrm{mL}(\mathrm{V}=1 \mathrm{~mL})(63)$, respectively. With GCMS-MS techniques, the LODs (LOQs) obtained in BL for the same compounds were: 1 (2.5) (V=1 mL)-20 (20) ng/mL (V= unknown) (59, 70); 1 (2.5)-2 (10) ng/mL (V=1 mL) (35, 70); 0.78 (1.56) $(\mathrm{V}=3 \mathrm{~mL})-2(10) \mathrm{ng} / \mathrm{mL}(\mathrm{V}=1 \mathrm{~mL})(31,35)$; no data available for 6-ACCOD; 0.5 (1) (V= $3 \mathrm{~mL})-25$ (250) ng/mL (V=2 mL) (47, 58); 0.5 (1) $(\mathrm{V}=3 \mathrm{~mL})-15(25) \mathrm{ng} / \mathrm{mL}(\mathrm{V}=1 \mathrm{~mL})(42,47) ; 0.1(0.1)$ $(\mathrm{V}=1 \mathrm{~mL})-50(50) \mathrm{ng} / \mathrm{mL}(\mathrm{V}=2 \mathrm{~mL})(57,58)$, respectively. Taking into account the technology (GC-MS) and the sample volume used $(250 \mu \mathrm{L})$, our results were quite satisfactory for all compounds in both matrices, when compared with those published.

Carryover was not observed in both matrices analyzed for each substance.

The values obtained in BL for intraday precision $(\mathrm{CV}<10.0 \%)$ and bias $(0.0-17.9 \%)$, such as intermediate precision $(\mathrm{CV}<8.3)$ and bias (0.0-19.4\%), were adequate. We also obtained acceptable results in $\mathrm{PF}$ for intraday precision $(\mathrm{CV}<8.4 \%)$ and bias $(0.0-18.4 \%)$ and for intermediate precision $(\mathrm{CV}<11.9)$ and bias $(0.0-13.8 \%)$. These results are presented in Tables III and IV.

The results obtained for the stability on the autosampler are summarized in Table V. All extracted substances were stable during $24 \mathrm{~h}$ in both biological matrices with \% differences between -19.0 and $3.7 \%$ for BL and between -17.1 and $5.0 \%$ for PF. At Table VI are presented both the benchtop stability and three freeze/thaw cycles (after 1, 2, 3 and 4 weeks). Regarding benchtop stability, all analytes were stable in BL and PF, with differences between -19.1 and $13.4(\mathrm{BL})$ and between -16.0 and $13.9 \%(\mathrm{PF})$. However, after three freeze/thaw cycles, there was only stability for all substances in PF with differences between -16.6 and $19.9 \%$. The results obtained to fentanyl during 7 days led to the need to reduce the analysis period to a shorter period of 5 days. Nevertheless, the results were similar, with the difference $>20 \%$, (out of the limits established by the SWGTOX) having noticed a progressive increase of this difference over the different periods. The study of this parameter with fortified samples may have affected the stability of fentanyl and led to a slightly different behavior from a real biological sample.

The mean of triplicate fortified samples were quantified within -12.0 to $16.4 \%$ in $\mathrm{BL}$ and -9.8 to $11.4 \%$ in PF, using $1: 2$ dilution factor. All the substances have shown adequate bias within the acceptance criteria of $\pm 20 \%$.

The results obtained for the extraction efficiency of the developed procedure in BL, for all concentration levels $(20,200$ and $900 \mathrm{ng} / \mathrm{mL})$ ranged between 32.7 and $87.6 \%$ for all the substances. Oxycodone and oxymorphone were the two substances with the lowest values $(<65.3 \%)$. These results are adequate since the obtained LOD and LOQ are sufficiently low in volumes of $250 \mu \mathrm{L}$ of BL. It was not possible to study this parameter in PF, because an unexpected formation of an emulsion occurred after adding the $1 \%$ aqueous hydroxylamine to the samples with unextracted standards (set 2). An insoluble material was also formed when the dried extracts were treated with the MSTFA $+5 \%$ TMCS solution. This side reaction may have occurred due to the formation of a salt of the neutralized acid during oximation, caused by an eventual $\mathrm{pH}$ change that prevented the complete reaction (71). However, the LOD and 


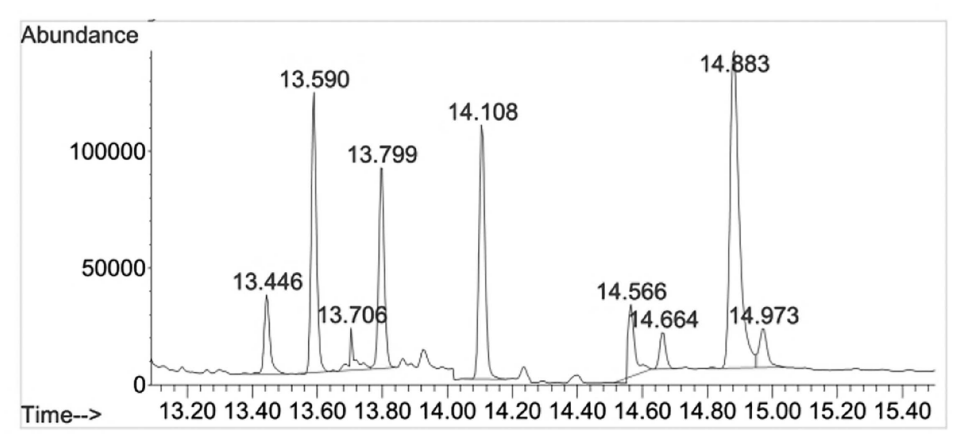

A

CodeineD3

MorphineD3

6-AcetylmorphineD3

FentanylD5

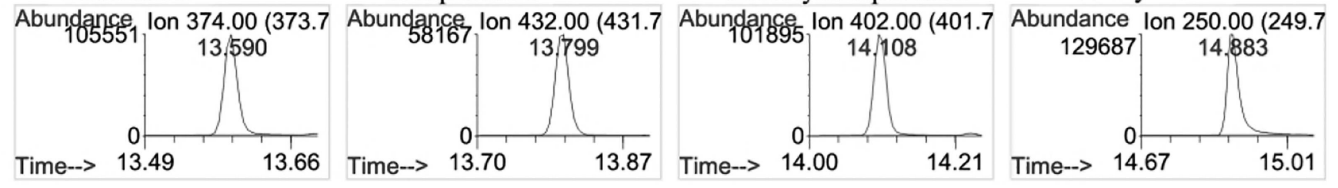

Codeine

Morphine

6-Acetylmorphine

Fentanyl

Abundance Ion 371.00 (370.7 Abundance Ion 429.00 (428.7 Abundance lon 399.00 (398.7 Abundance lon 245.00 (244.7

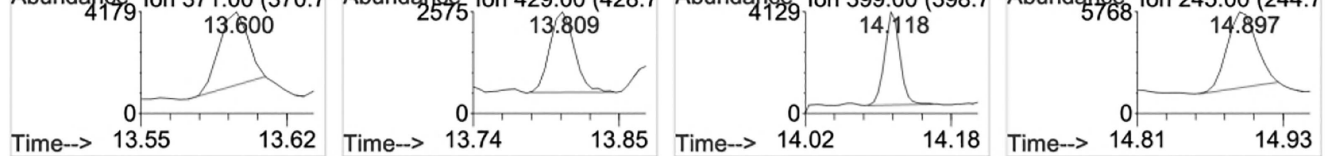

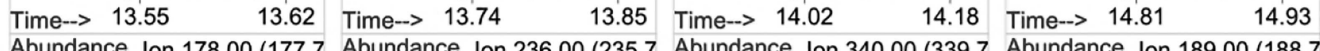

Abundance Ion 178.00 (177.7 Abundance Ion 236.00 (235.7 Abundance Ion 340.00 (339.7 Abundance Ion 189.00 (188.7

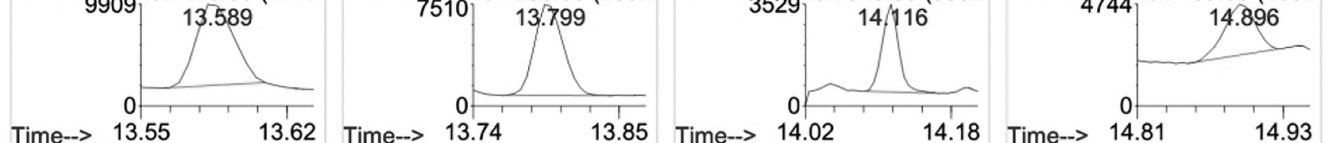

Abundance Ion 196.00 (195.7 Abundange Ion 414.00 (413.7 Abundance Ion 287.00 (286.7 Abundance Ion 146.00 (145.7

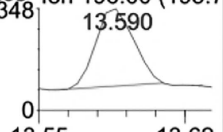

Time--> 13.55

13.62
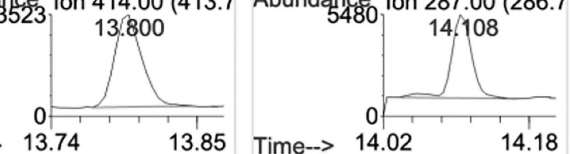

7727

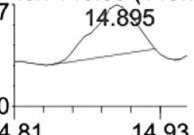

Oxycodone

6-Acetylcodeine

Oxymorphone

Abundange Ion 474.00 (473.7 Abundance Ion 341.00 (340.7 Abundap̧e If Ion 532.00 (531.7

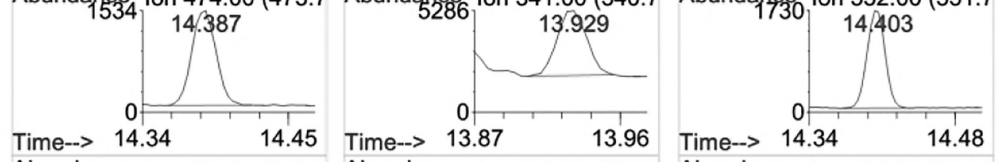

Abundance Ion 459.00 (458.7 Abundance Ion 229.00 (228.7 Abundance Ion 533.00 (532.7

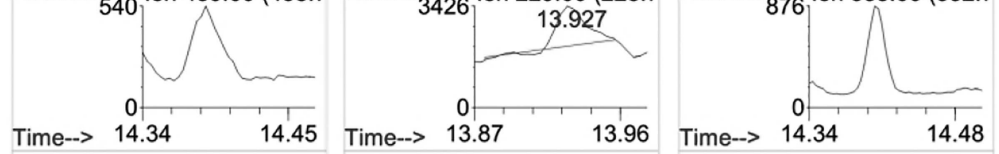

Abundance Ion 475.00 (474.7 Abundanfe Ion 282.00 (281.7 Abundance Ion 517.00 (516.7

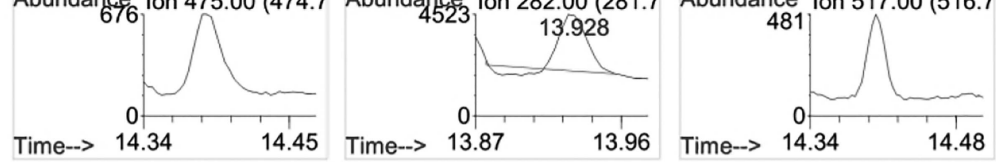

Figure 1. lon chromatograms of $B L(A)$ and $P F(B)$ samples fortified at the LOQ of each compound. 


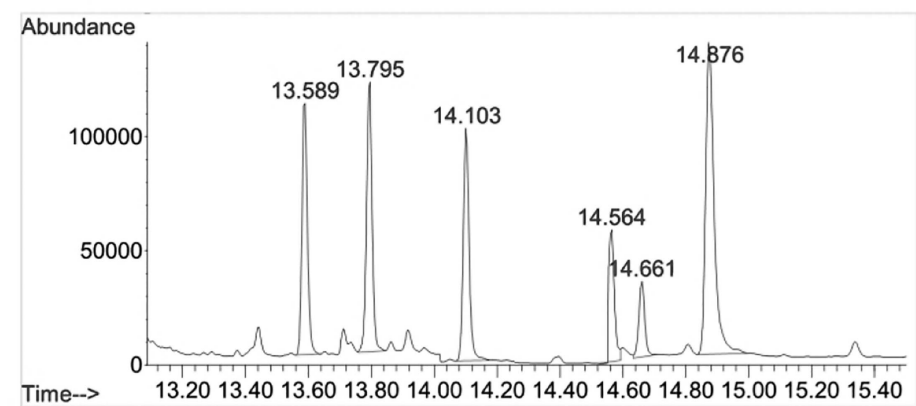

B

Time-->

CodeineD3

MorphineD3

6-AcetylmorphineD3

FentanylD5

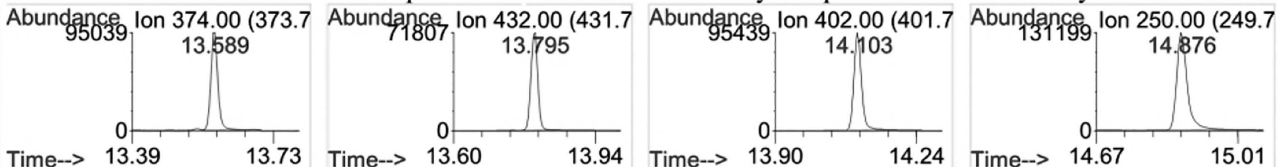

Codeine

Morphine

6-Acetylmorphine

Fentanyl

Abundance Ion 371.00 (370.7 Abundance Ion 429.00 (428.7 Abundance Ion 399.00 (398.7 Abundance Ion 245.00 (244.7

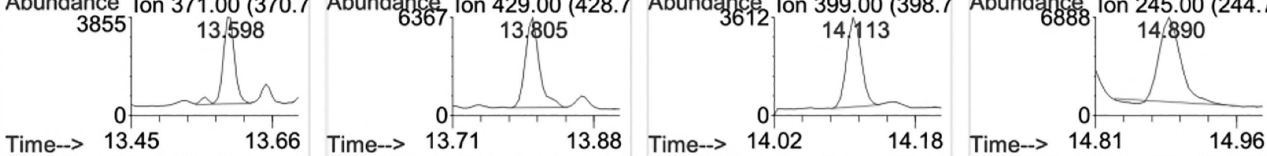

Abundance Ion 178.00 (177.7 Abundance Ion 236.00 (235.7 Abundance Ion 340.00 (339.7 Abundance Ion 189.00 (188.7
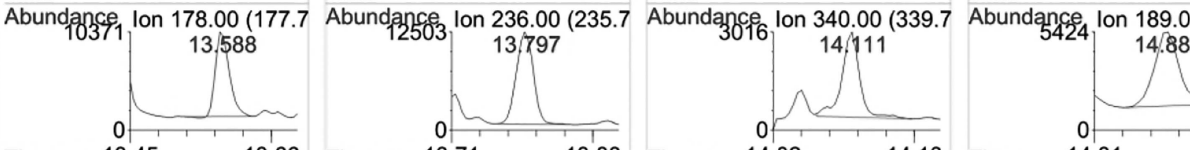

Time--> $13.45 \quad 13.66$ Time--> $13.71 \quad 13.88$

88 Time $\rightarrow 14.02$

14.18
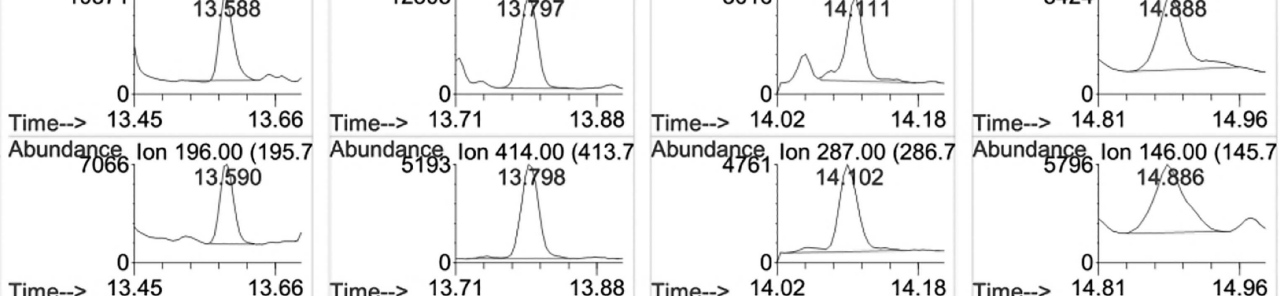

Time-->

3.45

13.66

6-Acetylcodeine

Oxymorphone

Oxycodone

4.18

14.81

14.96

Abundance Ion 474.00 (473.7 Abundance Ion 341.00 (340.7 Abundance Ion 532.00 (531.7

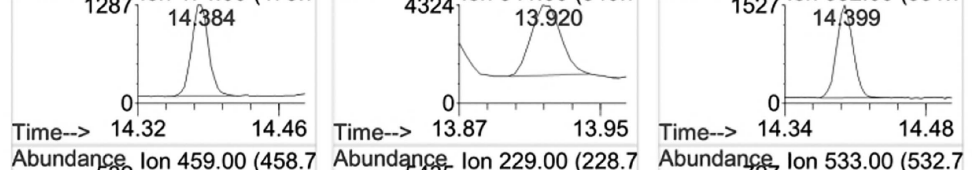

Abundance Ion 459.00 (458.7 Abundance Ion 229.00 (228.7 Abundance Ion 533.00 (532.7
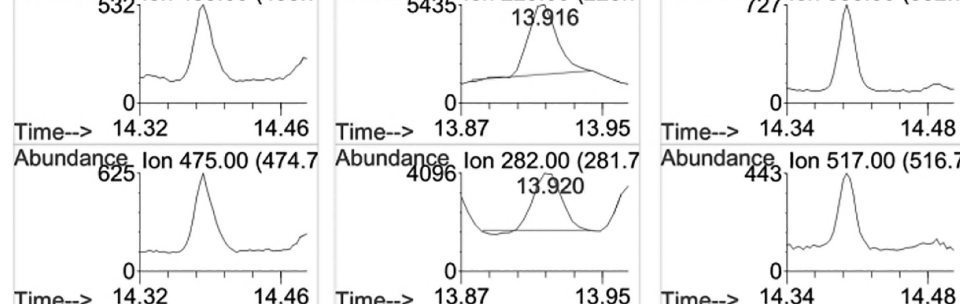

Figure 1. Ion chromatograms of $B L(A)$ and $P F(B)$ samples fortified at the $L O Q$ of each compound. 


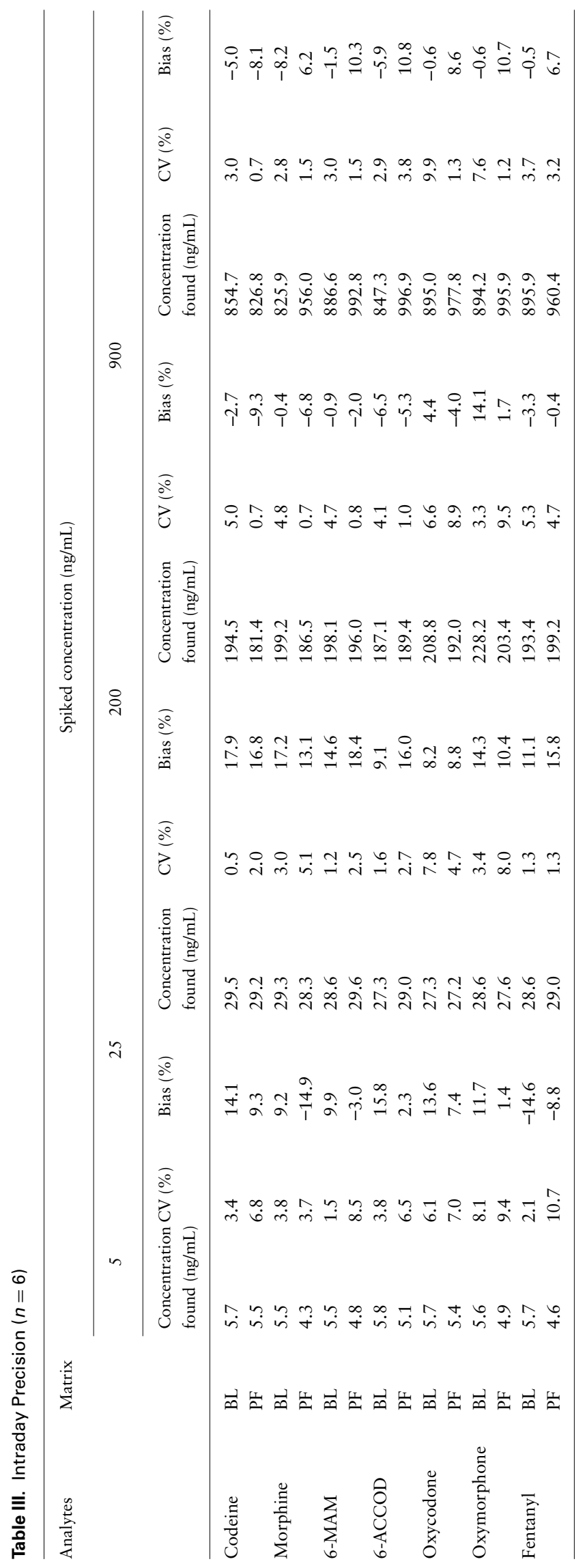


Table IV. Intermediate Precision $(n=15)$

\begin{tabular}{|c|c|c|c|c|c|c|c|c|c|c|}
\hline \multirow[t]{3}{*}{ Analytes } & \multirow[t]{3}{*}{ Matrix } & \multicolumn{9}{|c|}{ Spiked concentration $(\mathrm{ng} / \mathrm{mL})$} \\
\hline & & \multicolumn{2}{|l|}{25} & \multicolumn{2}{|c|}{200} & \multicolumn{3}{|c|}{900} & \multirow[b]{2}{*}{$\mathrm{CV}(\%)$} & \multirow[b]{2}{*}{ Bias $(\%)$} \\
\hline & & $\begin{array}{l}\text { Concentration } \\
\text { found }(\mathrm{ng} / \mathrm{mL})\end{array}$ & $\mathrm{CV}(\%)$ & Bias (\%) & $\begin{array}{l}\text { Concentration } \\
\text { found }(\mathrm{ng} / \mathrm{mL})\end{array}$ & $\mathrm{CV}(\%)$ & Bias $(\%)$ & $\begin{array}{l}\text { Concentration } \\
\text { found }(\mathrm{ng} / \mathrm{mL})\end{array}$ & & \\
\hline \multirow[t]{2}{*}{ Codeine } & $\mathrm{BL}$ & 29.7 & 1.4 & 18.8 & 218.8 & 5.2 & 9.4 & 918.7 & 3.1 & 2.1 \\
\hline & $\mathrm{PF}$ & 28.5 & 4.2 & 13.8 & 205.0 & 5.0 & 2.5 & 887.3 & 6.6 & -1.4 \\
\hline \multirow[t]{2}{*}{ Morphine } & $\mathrm{BL}$ & 28.6 & 5.1 & 14.6 & 233.6 & 1.7 & 16.8 & 912.8 & 1.6 & 1.4 \\
\hline & $\mathrm{PF}$ & 27.9 & 4.7 & 11.5 & 207.4 & 8.2 & 3.7 & 917.1 & 6.6 & 1.9 \\
\hline \multirow[t]{2}{*}{ 6-MAM } & $\mathrm{BL}$ & 29.0 & 3.3 & 16.0 & 225.1 & 4.1 & 12.6 & 918.9 & 1.4 & 2.1 \\
\hline & $\mathrm{PF}$ & 28.2 & 6.4 & 12.8 & 203.7 & 3.4 & 1.8 & 911.3 & 5.7 & 1.3 \\
\hline \multirow[t]{2}{*}{ 6-ACCOD } & $\mathrm{BL}$ & 28.6 & 4.8 & 14.5 & 216.2 & 5.4 & 8.1 & 945.4 & 3.3 & 5.0 \\
\hline & $\mathrm{PF}$ & 26.4 & 11.8 & 5.6 & 200.5 & 3.8 & 0.2 & 911.7 & 6.3 & 1.3 \\
\hline \multirow[t]{2}{*}{ Oxycodone } & $\mathrm{BL}$ & 28.9 & 6.8 & 15.7 & 222.6 & 5.9 & 11.3 & 860.2 & 8.3 & -4.4 \\
\hline & $\mathrm{PF}$ & 25.9 & 9.8 & 3.7 & 204.2 & 8.8 & 2.1 & 917.1 & 10.4 & 1.9 \\
\hline \multirow[t]{2}{*}{ Oxymorphone } & $\mathrm{BL}$ & 29.3 & 4.5 & 17.1 & 226.1 & 3.7 & 13.0 & 906.1 & 6.1 & 0.7 \\
\hline & $\mathrm{PF}$ & 27.1 & 11.2 & 8.5 & 206.5 & 8.6 & 3.2 & 919.9 & 10.3 & 2.2 \\
\hline \multirow{2}{*}{ Fentanyl } & $\mathrm{BL}$ & 29.8 & 1.1 & 19.4 & 205.8 & 3.3 & 2.9 & 933.7 & 2.5 & 3.7 \\
\hline & $\mathrm{PF}$ & 28.0 & 5.7 & 11.9 & 200.8 & 3.7 & 0.4 & 917.0 & 5.5 & 1.9 \\
\hline
\end{tabular}

Table V. Stability Data (\% Difference) after $24 \mathrm{~h}, 48 \mathrm{~h}$ and 7 days on the Autosampler $(n=3)$

\begin{tabular}{|c|c|c|c|c|c|c|c|c|c|c|}
\hline \multirow[t]{3}{*}{ Analytes } & \multirow[t]{3}{*}{ Matrix } & \multicolumn{3}{|c|}{ Autosampler $24 \mathrm{~h}$} & \multicolumn{3}{|c|}{ Autosampler $48 \mathrm{~h}$} & \multicolumn{3}{|c|}{ Autosampler 7 days } \\
\hline & & 20 & 200 & 900 & 20 & 200 & 900 & 20 & 200 & 900 \\
\hline & & & & & & $\mathrm{g} / \mathrm{mL})$ & & & & \\
\hline \multirow[t]{2}{*}{ Codeine } & $\mathrm{BL}$ & 2.9 & 0.5 & 0.5 & 8.9 & -0.4 & -0.1 & 8.6 & -6.1 & -3.5 \\
\hline & $\mathrm{PF}$ & 0.3 & 0.6 & 0.6 & 2.3 & 1.5 & -0.4 & 0.7 & -2.1 & -3.3 \\
\hline \multirow[t]{2}{*}{ Morphine } & $\mathrm{BL}$ & 1.8 & 0.3 & 0.2 & -16.9 & 1.6 & 0.3 & -12.3 & 3.9 & 4.3 \\
\hline & $\mathrm{PF}$ & 1.6 & 0.1 & 0.3 & 7.4 & 3.2 & 3.0 & 13.8 & 1.6 & 2.9 \\
\hline \multirow[t]{2}{*}{ 6-MAM } & $\mathrm{BL}$ & 2.2 & 0.7 & 0.0 & 0.1 & -0.9 & -0.2 & 5.1 & -6.1 & -4.3 \\
\hline & $\mathrm{PF}$ & -0.4 & -0.2 & 5.0 & -0.1 & 2.7 & 0.2 & 2.7 & -1.6 & -1.0 \\
\hline \multirow[t]{2}{*}{ 6-ACCOD } & $\mathrm{BL}$ & -1.7 & -2.5 & -0.6 & -17.9 & -8.4 & 0.5 & 5.3 & -5.9 & -0.3 \\
\hline & $\mathrm{PF}$ & -0.3 & -1.1 & -0.8 & 0.2 & -1.9 & -0.4 & 3.7 & 0.2 & -1.8 \\
\hline \multirow[t]{2}{*}{ Oxycodone } & $\mathrm{BL}$ & -19.0 & -14.9 & -8.6 & -15.3 & -15.3 & -13.6 & -61.7 & -57.1 & -54.0 \\
\hline & $\mathrm{PF}$ & -11.3 & -17.1 & -7.5 & -31.2 & -22.2 & -21.6 & -18.8 & -23.2 & -22.3 \\
\hline \multirow[t]{2}{*}{ Oxymorphone } & $\mathrm{BL}$ & -11.9 & -7.2 & -4.0 & -9.3 & -10.4 & -9.4 & -33.6 & -32.9 & -31.0 \\
\hline & $\mathrm{PF}$ & -8.4 & -11.7 & -7.2 & -19.9 & -19.9 & -13.5 & -8.4 & -13.1 & -11.9 \\
\hline \multirow[t]{2}{*}{ Fentanyl } & $\mathrm{BL}$ & 3.7 & 0.4 & 0.9 & 6.3 & 2.7 & -0.5 & 9.4 & -0.6 & -1.3 \\
\hline & $\mathrm{PF}$ & 1.4 & -0.3 & 0.9 & 3.8 & 2.3 & 2.0 & 1.2 & -0.3 & -1.2 \\
\hline
\end{tabular}

LOQ reached in $250 \mu \mathrm{L}$ of $\mathrm{PF}$ were low enough to demonstrate that the method is sensitive.

\section{Method application}

The applicability of the method was evaluated by their application to 44 and $31 \mathrm{BL}$ and PF samples, respectively. In BL, we had 11 positive results for codeine $(5.8-54.8 \mathrm{ng} / \mathrm{mL}), 33$ for morphine (4.2-386.0 ng/mL), 4 for 6-MAM $(4.6-13.2 \mathrm{ng} / \mathrm{mL})$ and 3 for fentanyl $(4.4-45.2 \mathrm{ng} / \mathrm{mL})$. We had only one positive result in PF: codeine $(50.2 \mathrm{ng} / \mathrm{mL})$, morphine $(540.4 \mathrm{ng} / \mathrm{mL})$ and $6-\mathrm{MAM}$ $(5.3 \mathrm{ng} / \mathrm{mL})$ (Figure $2 \mathrm{~A}$ and B).

The restricted number of positive cases in PF and the absence of positive cases for some of the substances (6-ACCOD, oxycodone, oxymorphone and fentanyl) is the main limitation of our methodology, considering the existence of records that they are consumed and the evolution on its consumption. However, the case samples were from $>2$ years ago, and according to the obtained stability results most of the substances degrades over time; this can be an explanation for the lack of positive results.

\section{Conclusion}

We were able to develop a sensitive and selective methodology combining the SPE extraction and the analyses by gas chromatography with a single quadrupole mass spectrometer for the determination of opioids and some metabolites in volumes of $250 \mu \mathrm{L}$ of BL and PF. Since often small amounts of samples are available to perform 


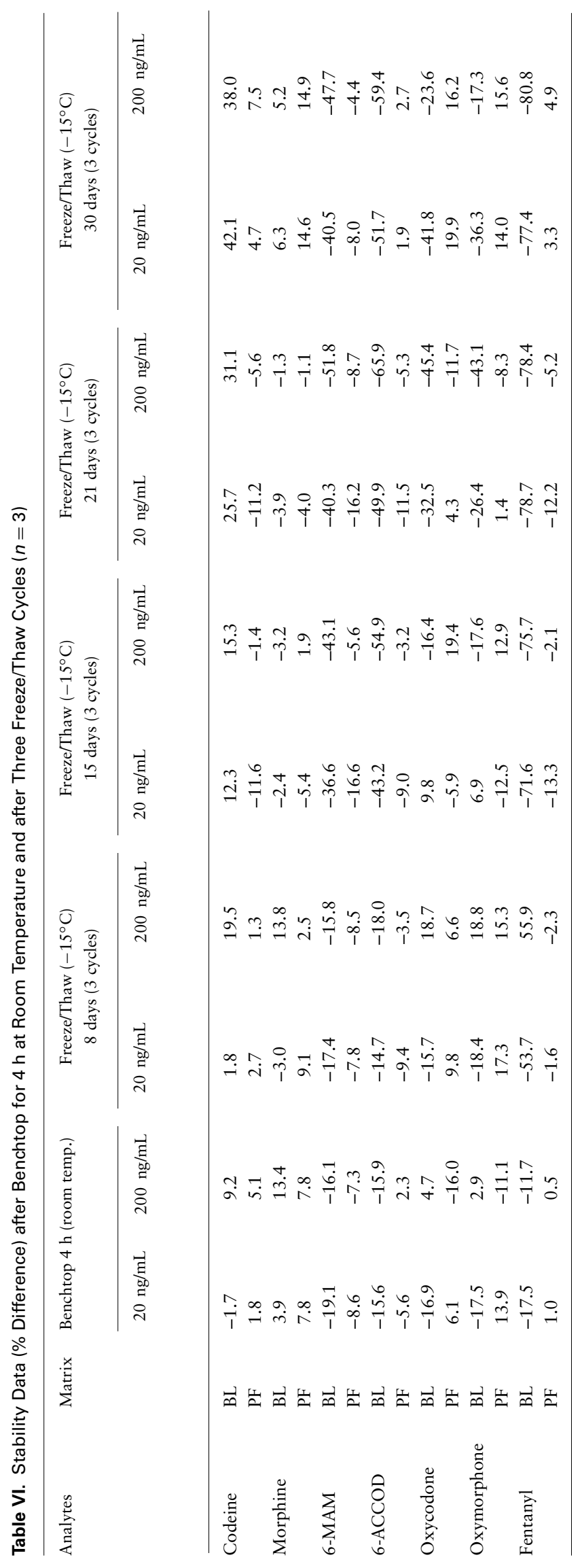




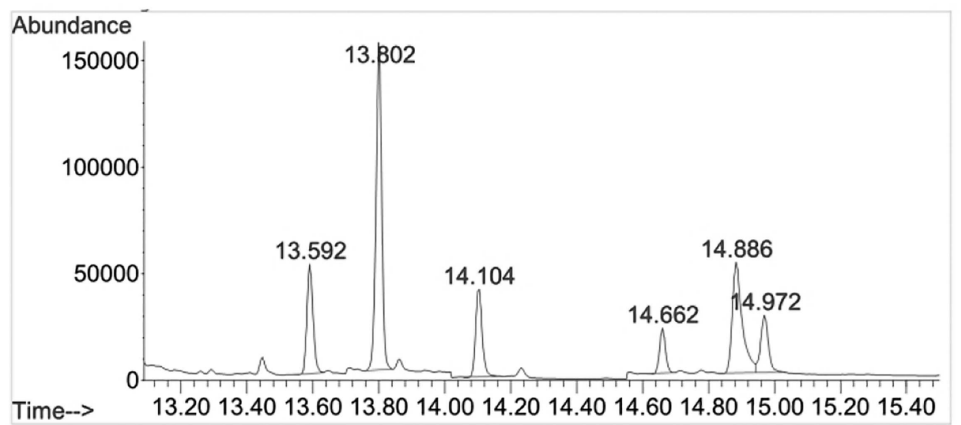

A
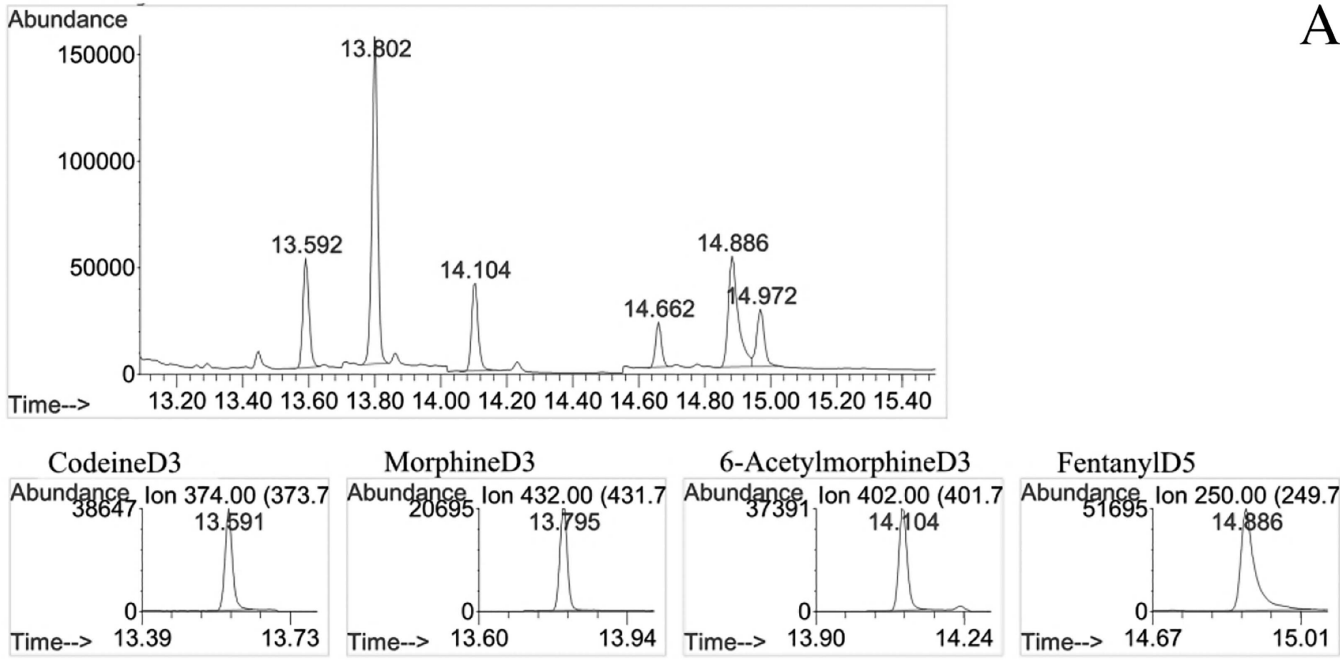

Codeine

Morphine

6-Acetylmorphine

Fentanyl

Abundance Ion 371.00 (370.7 Abundance Ion 429.00 (428.7 Abundance lon 399.00 (398.7 Abundance lon 245.00 (244.7

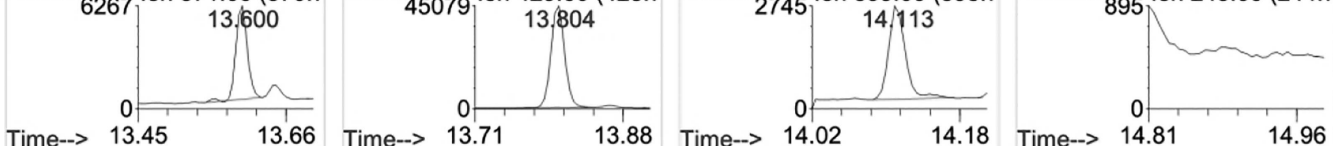

Abundance Ion 178.00 (177.7 Abundance Ion 236.00 (235.7 Abundance Ion 340.00 (339.7 Abundance lon 189.00 (188.7
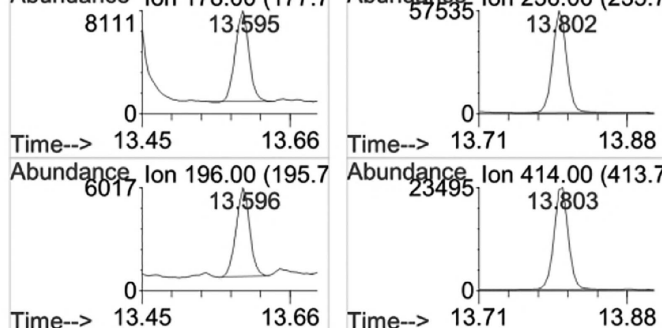

Time--> 13.71

13.88
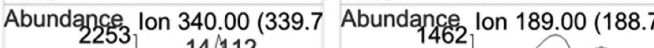

Oxycodone 13.66
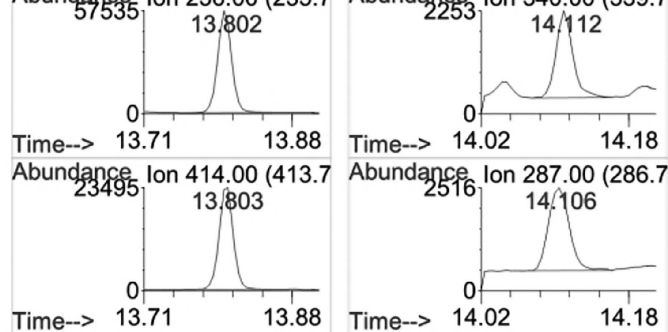

14.18 Time--> 14.81
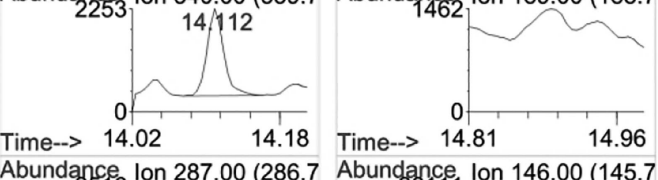
Abundance Ion 474.00 (473.7 Abundance Ion 341.00 (340.7 Abundance lon 532.00 (531.7

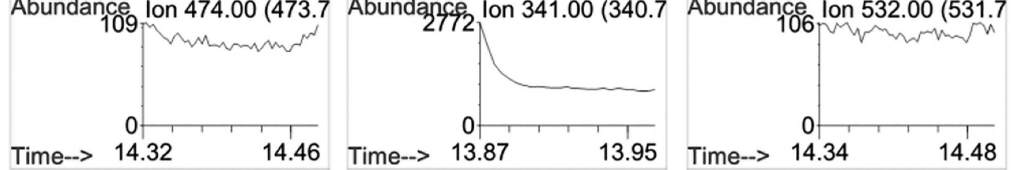

Abundance Ion 459.00 (458.7 Abundance Ion 229.00 (228.7 Abundance Ion 533.00 (532.7

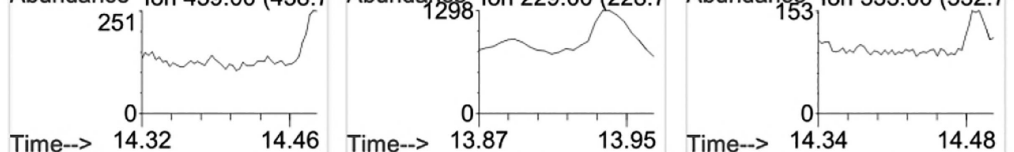

Abundance Ion 475.00 (474.7 Abundance Ion 282.00 (281.7 Abundance Ion 517.00 (516.7

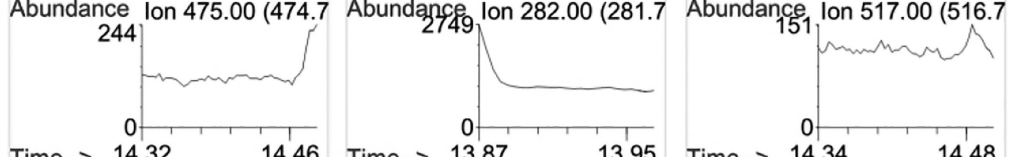

Figure 2. Ion chromatograms of authentic $B L(A)$ and $P F(B)$ samples. 


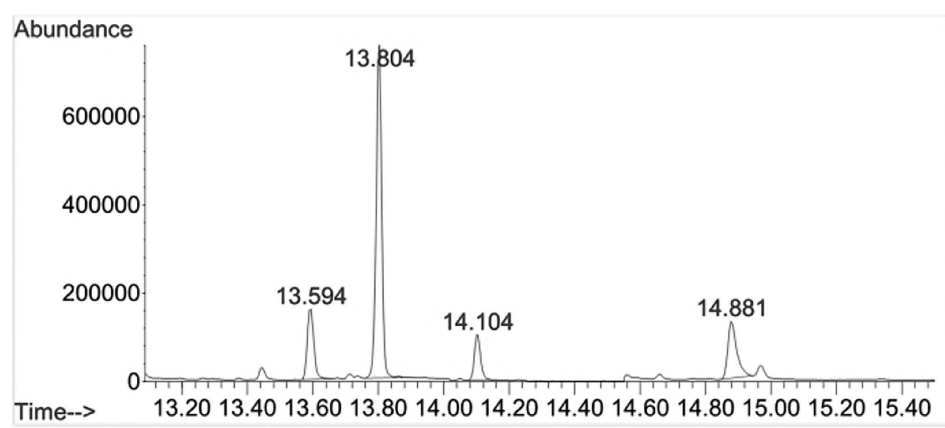

B

CodeineD3

MorphineD3

6-AcetylmorphineD3

FentanylD5

Abundance Ion 374.00 (373.7 Abundance Ion 432.00 (431.7 Abundance lon 402.00 (401.7 Abundance lon 250.00 (249.7
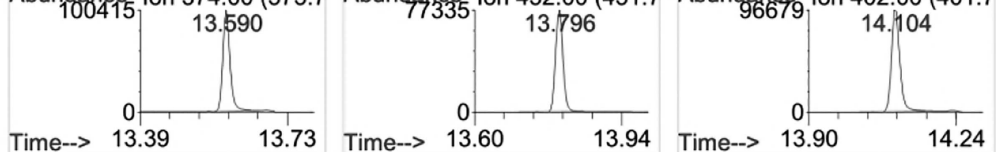

130255

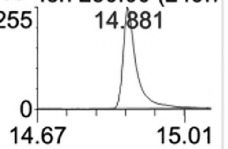

Codeine

Morphine

6-Acetylmorphine

Fentanyl

$\begin{array}{ccc}\text { Abundance Ion } 371.00(370.7 & \text { Abundance Ion } 429.00 \text { (428.7 Abundange } \\ 31607 & \text { Ion } 399.00 \text { (398.7 Abundance lon } 245.00(244.7\end{array}$
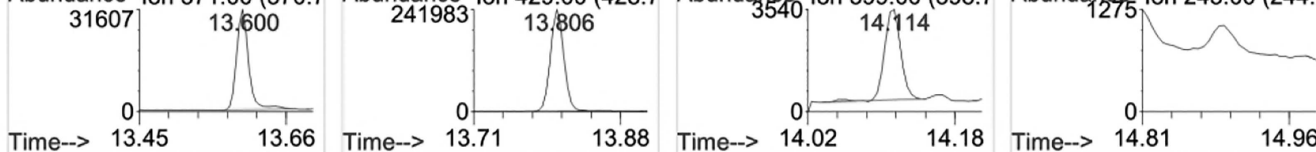

Abundance Ion 178.00 (177.7 Abundance Ion 236.00 (235.7 Abundance Ion 340.00 (339.7 Abundance Ion 189.00 (188.7
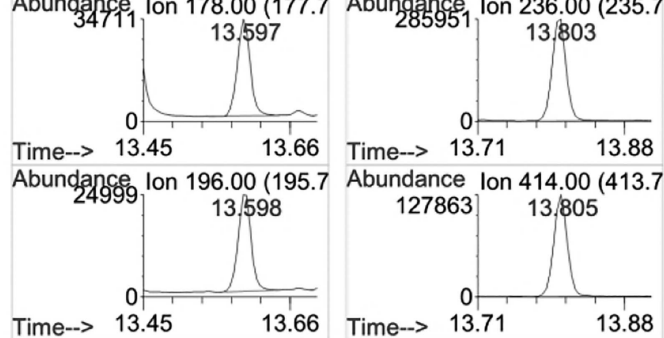

Time--> 13.71

13.88 Time--> 14.02
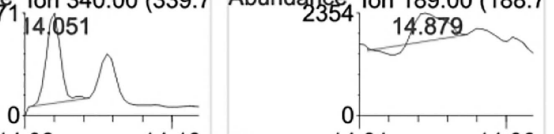

Time--> 13.45

Abundance Ion 414.00
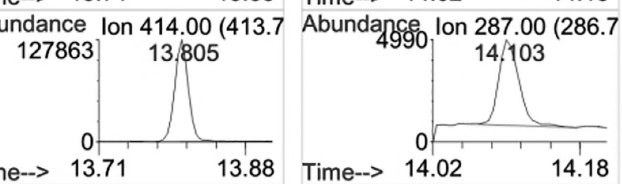

Time--> $14.81 \quad 14.96$

Oxycodone

6-Acetylcodeine

Oxymorphone

Abundance Ion 474.00 (473.7 Abundance Ion 341.00 (340.7 Abundance lon 532.00 (531.7

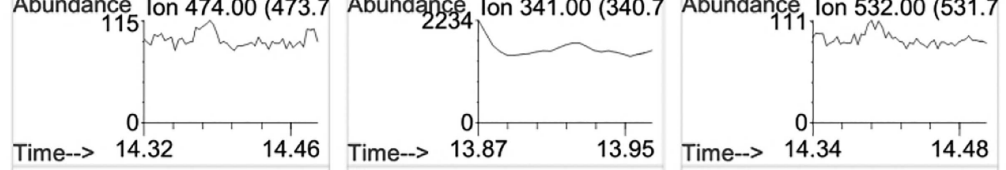

Abundance Ion 459.00 (458.7 Abundance Ion 229.00 (228.7 Abundance Ion 533.00 (532.7

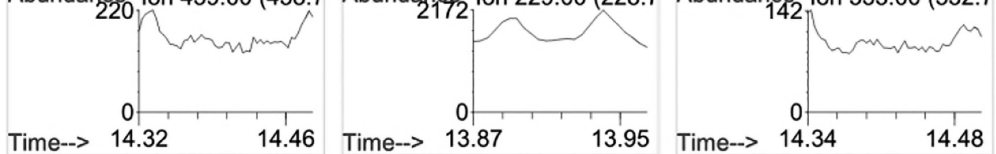

Abundance lon 475.00 (474.7 Abundange Ion 282.00 (281.7 Abundance Ion 517.00 (516.7

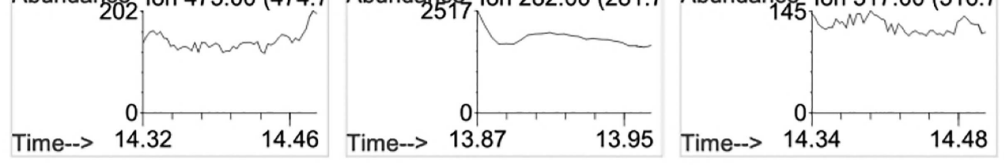

Figure 2. lon chromatograms of authentic $B L(A)$ and $P F(B)$ samples. 
all the required toxicological analyses, only $250 \mu \mathrm{L}$ of required volume sample is very useful. This new methodology brings several advantages like the small sample and solvents volumes required and the low limits (LOD and LOQ) obtained for all the substances. The optimization of two microwave-assisted derivatizations (30 and $100 \mathrm{~s}$ ) contributed to the reduction of the total time of the assay when compared to previous studies. Another advantage in the utilization of the GC-MS analytical instrumentation relates to its availability in most toxicology laboratories and because it offers robustness, sensitivity and is less expensive than other technologies.

To our knowledge, this is the first procedure developed for the simultaneous determination of codeine, morphine, 6-MAM, 6ACCOD, oxycodone, oxymorphone and fentanyl in whole $\mathrm{BL}$ and PF with microwave-assisted derivatization with both $1 \%$ aqueous hydroxylamine and MSTFA + 5\% TMCS.

Furthermore, the results indicate the methodology suitability for the application in forensic toxicology laboratories in the routine analysis of these compounds. Thus, the developed methodology prepares the forensic toxicology laboratory for future requests and for the unpredictable detection of these substances in the routine casework.

\section{References}

1. Maas, A., Madea, B., Hess, C. (2018) Confirmation of recent heroin abuse: accepting the challenge. Drug Testing and Analysis, 10, 54-71.

2. Milone, M.C. (2012) Laboratory testing for prescription opioids. Journal of Medical Toxicology, 8, 408-416.

3. Koyyalagunta, D. Opioid analgesics. In: Waldman S. (ed). Pain Management. Saunders-Elsevier: New York, NY, 2006; pp939-964.

4. Verplaetse, R., Henion, J. (2016) Quantitative determination of opioids in whole blood using fully automated dried blood spot desorption coupled to on-line SPE-LC-MS/MS. Drug Testing and Analysis, 8, 30-38.

5. Karch, S.B. Drug Abuse Handbook. CRC Press LLC: New York, 1998.

6. Costa, C.A., Santos, C., Alves, P., Costa, A. (2007) Dor oncológica. Revista Portuguesa de Pneumologia, XIII, 855-867.

7. Dickenson, T. Opiates and Opioids. John Wiley \& Sons, Ltd: Chichester, UK, 2012.

8. Reisine, T., Bell, G.I. (1993) Molecular biology of opioid receptors. Trends in Neurosciences, 16, 506-510.

9. Harkouk, H., Pares, F., Daoudi, K., Fletcher, D. (2018) Farmacología de los opioides. EMC - Anestesia-Reanimación, 44, 1-24.

10. Herz, A. (ed) Handbook of Experimental Pharmacology, Vol. 140, 1st edition. Springer: Berlin Heidelberg, 1993.

11. Anderson, I.B., Benowitz, N.L., Blanc, P.D., Clark, R.F., Kearney, T.E., Kimkatz, S.Y., et al. Manual de Toxicologia Clínica, 6a edition. AMGH Editora Ltda: Porto Alegre, 2014.

12. Concheiro, M., Chesser, R., Pardi, J., Cooper, G. (2018) Postmortem toxicology of new synthetic opioids. Frontiers in Pharmacology, 9, 1-18.

13. United Nations Office on Drugs and Crime (UNODC) (2018) World Drug Report. 2018. https://www.unodc.org/wdr2018 (accessed 6 July 2019).

14. Observatório Europeu da Droga e Toxicodependência Relatório Europeu sobre Drogas Tendências e evoluções. Observatório Europeu da Droga e Toxicodependência: Luxemburgo, 2018.

15. Serviço de Intervenção nos Comportamentos Aditivos e nas Dependências: Direção de Serviços de Monitorização e Informação/Divisão de Estatística e Investigação Relatório Anual- A Situação do País em Matéria de Drogas $e$ Toxicodependências, 2018th edition. Serviço de Intervenção nos Comportamentos Aditivos e nas Dependências. 2017. www.sicad.pt.

16. European Monitoring Centre for Drugs and Drug Addiction European Drug Report 2019: Trends and Developments. Publications Office of the European Union: Luxembourg, 2019.

17. UNODC (2018) Opioid Strategy. Predict, Prevent, Protect. https://www. unodc.org/unodc/en/opioid-crisis/index.html (accessed 17 June 2019).
18. Contreras, M.T., Hernández, A.F., González, M., González, S., Ventura, R., Pla, A., et al. (2006) Application of pericardial fluid to the analysis of morphine (heroin) and cocaine in forensic toxicology. Forensic Science International, 164, 168-171.

19. Álvarez-Freire, I., Brunetti, P., Cabarcos-Fernández, P., Fernández-Liste, A., Tabernero-Duque, M.J., Bermejo-Barrera, A.M. (2018) Determination of benzodiazepines in pericardial fluid by gas chromatography - mass spectrometry. Journal of Pharmaceutical and Biomedical Analysis, 159, $45-52$.

20. Moriya, F., Hashimoto, Y. (1999) Pericardial fluid as an alternative specimen to blood for postmortem toxicological analyses. Legal Medicine, $1,86-94$.

21. Margalho, C., Gallardo, E., Castanheira, A., Vieira, D.N., López-Rivadulla, M., Real, F.C. (2013) A validated procedure for detection and quantitation of salvinorin a in pericardial fluid, vitreous humor, whole blood and plasma using solid phase extraction and gas chromatography-mass spectrometry. Journal of Chromatography A, 1304, 203-210.

22. Contreras, M.T., González, M., González, S., Ventura, R., Valverde, J.L., Hernández, A.F., et al. (2007) Validation of a procedure for the gas chromatography-mass spectrometry analysis of cocaine and metabolites in pericardial fluid. Journal of Analytical Toxicology, 31, 75-80.

23. Tominaga, M., Michiue, T., Ishikawa, T., Kawamoto, O., Oritani, S., Ikeda, K., et al. (2013) Postmortem analyses of drugs in pericardial fluid and bone marrow aspirate. Journal of Analytical Toxicology, 37, 423-429.

24. Thaulow, C.H., Øiestad, Å.M.L., Rogde, S., Karinen, R., Brochmann, G.W., Andersen, J.M., et al. (2018) Metabolites of heroin in several different post-mortem matrices. Journal of Analytical Toxicology, 42, 311-320.

25. Roskar, R., Trdan, T. (2012) Analytical methods for quantification of drug metabolites in biological samples. Edited by Leonardo de Azevedo Calderon. Chromatography-The Most Versatile Method of Chemical Analysis, 2012. doi: 10.5772/51676.

26. Poole, C.F. Principles and practice of solid-phase extraction. In: Pawliszyn J. (ed). Comprehensive Analytical Chemistry, Vol. XXXVII. Elsevier B.V, 2012; pp341-387.

27. Barroso, M., Gallardo, E., Vieira, D.N., Queiroz, J.A., López-Rivadulla, M. (2011) Bioanalytical procedures and recent developments in the determination of opiates/opioids in human biological samples. Analytical and Bionalytical Chemistry, 400, 1665-1690.

28. Moeller, M.R., Steinmeyer, S., Kraemer, T. (1998) Determination of drugs of abuse in blood. Journal of Chromatography B, 713, 91-109.

29. Margalho, C., Castanheira, A., Real, F.C., Gallardo, E., López-Rivadulla, M. (2016) Determination of "new psychoactive substances" in postmortem matrices using microwave derivatization and gas chromatography - mass spectrometry. Journal of Chromatography B, 1020, 14-23.

30. Jones, J., Tomlinson, K., Moore, C. (2002) The simultaneous determination of codeine, morphine, hydrocodone, hydromorphone, 6acetylmorphine, and oxycodone in hair and oral fluid. Journal of Analytical Toxicology, 26, 171-175.

31. Lewis, R.J., Johnson, R.D., Hattrup, R.A. (2005) Simultaneous analysis of Thebaine, 6-MAM and six abused opiates in postmortem fluids and tissues using Zymark ${ }^{\circledR}$ automated solid-phase extraction and gas chromatography - Mass spectrometry. Journal of Chromatography B, 822, 137-145.

32. Halket, J.M., Zaikin, V.G. (2003) Derivatization in mass spectrometry 1. silylation. European Journal of Mass Spectrometry, 9, 1-21.

33. Ropero-Miller, J.D., Lambing, M.K., Winecker, R.E. (2002) Simultaneous quantitation of opioids in blood by GC-EI-MS analysis following deproteination, detautomerization of keto analytes, solid-phase extraction, and trimethylsilyl derivatization. Journal of Analytical Toxicology, 26, 524-528.

34. Meatherall, R. (1999) GC-MS confirmation of codeine, morphine, 6acetylmorphine, hydrocodone, hydromorphone, oxycodone, and oxymorphone in urine*. Journal of Analytical Toxicology, 23, 177-186.

35. Meatherall, R. (2005) GC-MS quantitation of codeine, morphine, 6acetylmorphine, hydrocodone, hydromorphone, oxycodone, and oxymorphone in blood*. Journal of Analytical Toxicology, 29, 301-308. 
36. Moore, C., Rana, S., Coulter, C. (2007) Determination of meperidine, tramadol and oxycodone in human oral fluid using solid phase extraction and gas chromatography-mass spectrometry. Journal of Chromatography $B, 850,370-375$.

37. Vorce, S.P., Levine, B., McDonough, P.C., Past, M.R. (2010) An overdose death involving the insufflation of extended-release oxymorphone tablets*, †. Journal of Analytical Toxicology, 34, 521-526.

38. Knittel, J.L., Clay, D.J., Bailey, K.M., Gebhardt, M.A., Kraner, J.C. (2009) Comparison of oxycodone in vitreous humor and blood using EMIT ${ }^{\circledR}$ screening and gas chromatographic - mass spectrometric quantitation. Journal of Analytical Toxicology, 33, 433-438.

39. Broussard, L.A., Presley, L.C., Pittman, T., Clouette, R., Wimbish, G.H. (1997) Simultaneous identification and quantitation of codeine, morphine, hydrocodone, and hydromorphone in urine as trimethylsilyl and oxime derivatives by gas chromatography-mass spectrometry. Clinical Chemistry, 43, 1029-1032.

40. McDonough, P.C., Levine, B., Vorce, S., Jufer, R.A., Fowler, D. (2008) The detection of hydromorphone in urine specimens with high morphine concentrations. Journal of Forensic Sciences, 53, 752-754.

41. Backer, R.C., Monforte, J.R., Poklis, A. (2005) Evaluation of the DRI ${ }^{\circledR}$ oxycodone immunoassay for the detection of oxycodone in urine. Journal of Analytical Toxicology, 29, 675-677.

42. Garside, D., Hargrove, R.L., Winecker, R.E. (2009) Concentration of oxymorphone in postmortem fluids and tissue *. Journal of Analytical Toxicology, 33, 121-128.

43. Aleksa, K., Walasek, P., Fulga, N., Kapur, B., Gareri, J., Koren, G. (2012) Simultaneous detection of seventeen drugs of abuse and metabolites in hair using solid phase micro extraction (SPME) with GC/MS. Forensic Science International, 218, 31-36.

44. Nowatzke, W., Zeng, J., Saunders, A., Bohrer, A., Koenig, J., Turk, J. (1999) Distinction among eight opiate drugs in urine by gas chromatographymass spectrometry. Journal of Pharmaceutical and Biomedical Analysis, $20,815-828$.

45. Chen, B.G., Wang, S., Liu, R.H. (2007) GC-MS analysis of multiply derivatized opioids in urine. Journal of Mass Spectrometry: JMS, 42, 1012-1023.

46. McKinley, S.G., Snyder, J.J., Welsh, E., Kazarian, C.M., Jamerson, M.H., Klette, K.L. (2007) Rapid quantification of urinary oxycodone and oxymorphone using fast gas chromatography-mass spectrometry. Journal of Analytical Toxicology, 31, 434-441.

47. Kokki, H., Rasanen, I., Lasalmi, M., Lehtola, S., Ranta, V., Vanamo, K., et al. (2006) Comparison of oxycodone pharmacokinetics after buccal and sublingual administration in children. Clinical Pharmacokinetics, 45 , $745-754$

48. Chung, L.W., Lin, K.L., Yang, T.C.C., Lee, M.R. (2009) Orthogonal array optimization of microwave-assisted derivatization for determination of trace amphetamine and methamphetamine using negative chemical ionization gas chromatography-mass spectrometry. Journal of Chromatography A, 1216, 4083-4089.

49. Chung, L.W., Liu, G.J., Li, Z.G., Chang, Y.Z., Lee, M.R. (2008) Solventenhanced microwave-assisted derivatization following solid-phase extraction combined with gas chromatography-mass spectrometry for determination of amphetamines in urine. Journal of Chromatography B, 874, $115-118$.

50. Damm, M., Rechberger, G., Kollroser, M., Kappe, C.O. (2009) An evaluation of microwave-assisted derivatization procedures using hyphenated mass spectrometric techniques. Journal of Chromatography A, 1216, 5875-5881.

51. Söderholm, S.L., Damm, M., Kappe, C.O. (2010) Microwave-assisted derivatization procedures for gas chromatography/mass spectrometry analysis. Molecular Diversity, 14, 869-888.

52. De Brabanter, N., Van Gansbeke, W., Hooghe, F., Van Eenoo, P. (2013) Fast quantification of 11-nor- $\Delta$ 9-tetrahydrocannabinol-9carboxylic acid (THCA) using microwave-accelerated derivatisation and gas chromatography-triple quadrupole mass spectrometry. Forensic Science International, 224, 90-95.
53. Meng, P., Zhu, D., He, H., Wang, Y., Guo, F., Zhang, L. (2009) Determination of amphetamines in hair by GC/MS after small-volume liquid extraction and microwave derivatization. Analytical Sciences, 25, 1115-1118.

54. Scientific Working Group for Forensic Toxicology (2013) Scientific Working Group for Forensic Toxicology (SWGTOX) standard practices for method validation in forensic toxicology report from the Scientific Working Group for Forensic Toxicology. Journal of Analytical Toxicology, 37, 452-474.

55. World Anti-Doping Agency Project Team. WADA Technical Document - TD2015IDCR: Minimum Criteria for Chromatographic-Mass Spectrometric Confirmation of the Identity of Analytes For Doping Control Purposes. (2015-09-01). https://www.wada-ama.org/en/resources/ science-medicine/td2015idcr (accessed 27 May 2019).

56. Thompson, J.G., Vanderwerf, S., Seningen, J., Carr, M., Kloss, J., Apple, F.S. (2008) Free oxycodone concentrations in 67 postmortem cases from the Hennepin County medical examiner's office. Journal of Analytical Toxicology, 32, 673-679.

57. Bertol, E., Focardi, M., Defraia, B., De Luca, F., Vaiano, F., Mari, F. (2013) An unusual homicide involving strangulation after transdermal fentanyl and buprenorphine intoxication. Journal of Forensic Toxicology \& Pharmacology, 2, 1-4.

58. Juhascik, M.P., Jenkins, A.J. (2009) Comparison of liquid/liquid and solidphase extraction for alkaline drugs. Journal of Chromatographic Science, 47, 553-557.

59. Love, S.A., Lelinski, J., Kloss, J., Middleton, O., Apple, F.S. (2018) Heroinrelated deaths from the Hennepin county medical examiner's office from 2004 through 2015. Journal of Forensic Sciences, 63, 191-194.

60. Derienz, R.T., Baker, D.D., Kelly, N.E., Mullins, A.M., Barnett, R.Y., Hobbs, J.M., et al. (2018) Child fatalities due to heroin/fentanyl exposure: what the case history missed. Journal of Analytical Toxicology, 42, 581-585.

61. Anderson, D.T., Fritz, K.L., Muto, J.J. (2002) Oxycontin ${ }^{\circledR}$ : the concept of a "ghost pill" and the postmortem tissue distribution of oxycodone in 36 cases*. Journal of Analytical Toxicology, 26, 448-459.

62. Al-Asmari, A.I., Anderson, R.A. (2007) Method for quantification of opioids and their metabolites in autopsy blood by liquid chromatographytandem mass spectrometry. Journal of Analytical Toxicology, 31,394-408.

63. Gergov, M., Nokua, P., Vuori, E., Ojanpera, I. (2009) Simultaneous screening and quantification of 25 opioid drugs in post-mortem blood and urine by liquid chromatography - tandem mass spectrometry. Forensic Science International, 186, 36-43.

64. Yang, C., Liu, H., Lin, D., Liu, R.H., Hsieh, Y., Wu, S. (2017) Simultaneous quantitation of methamphetamine, ketamine, opiates and their metabolites in urine by SPE and LC - MS-MS. Journal of Analytical Toxicology, 41, 679-687.

65. Dziadosz, M., Teske, J., Henning, K., Klintschar, M., Nordmeier, F. (2018) LC-MS/MS screening strategy for cannabinoids, opiates, amphetamines, cocaine, benzodiazepines and methadone in human serum, urine and postmortem blood as an effective alternative to immunoassay based methods applied in forensic toxicology for preliminary. Forensic Chemistry, 7, 33-37.

66. Feliu, C., Millart, H., Guillemin, H., Vautier, D., Binet, L., Fouley, A., et al. (2015) Validation of a fast UPLC-MS/MS method for quantitative analysis of opioids, cocaine, amphetamines (and their derivatives) in human whole blood. Bioanalysis, 7, 2685-2700.

67. Coles, R., Kushnir, M.M., Nelson, G.J., McMillin, G.A., Urry, F.M. (2007) Simultaneous determination of codeine, morphine, hydrocodone, hydromorphone, oxycodone, and 6-acetylmorphine in urine, serum, plasma, whole blood, and meconium by LC-MS-MS. Journal of Analytical Toxicology, 31, 1-14.

68. Fritch, D., Blum, K., Nonnemacher, S., Haggerty, B.J., Sullivan, M.P., Cone, E.J. (2009) Identification and quantitation of amphetamines, cocaine, opiates, and phencyclidine in oral fluid by liquid chromatography-tandem mass spectrometry. Journal of Analytical Toxicology, 33, 569-577.

69. Wang, J., Yang, Z., Lechago, J. (2013) Rapid and simultaneous determination of multiple classes of abused drugs and metabolites in human urine 
by a robust LC-MS/MS method - application to urine drug testing in pain clinics. Biomedical Chromatography, 27, 1463-1480.

70. Saad, M.A. AL, Abu-Rumman, A.M., Mohamed, K.M. (2019) A gas chromatography-triple quadrupole mass spectrometry assay for the quan- tification of opiates in human blood samples. Journal of Analytical Tox icology, 43, 185-195. https://academic.oup.com/jat/advance-article/doi/ 10.1093/jat/bky077/5122740.

71. Rooij, A.H.D. Preparation of Oxime, 1969; p1969. 